\title{
Model Pemgembangan Mutu Pendidikan Dalam Perspektif Philip. B. Crosby
}

\section{Quality Education Development Models In The Philip Perspective. B. Crosby}

\author{
Marita Lailia Rahman \\ ${ }^{1}$ Institut Agama Islam Tribakti Kediri, Indonesia \\ ${ }^{1}$ lailia.marita@gmail.com
}

\begin{abstract}
Some figures present the concept of quality to the world's corporate which then many scientists have adopted for the education's world. The famous Deming's quality concept is plan, do, check, analyze, while the famous Juran's quality concept is quality planning, quality controlling, and quality improvement. All these concepts if applicable in the world of education will have a positive impact on the improvement of quality's education. Some figures as Philip Crosby offer some strategies to increase quality. It can be adopted for educational institution to improve its quality. Crosby offer Zero Defect concept that explained for fourteen steps to applicate in every educational institution in order to manage and improve education's quality. Every manager or the leader of educational institution should always innovate and develop their educational institutions so that students can compete in the era of globalization.
\end{abstract}

Key Word: Quality Development Model Education, Education, Philip B. Crosby

\begin{abstract}
Abstrak
Beberapa tokoh menyajikan konsep mutu untuk dunia perusahaan yang kemudian banyak para ilmuwan yang mengadopsinya untuk dunia pendidikan. Konsep mutu Deming yang terkenal adalah plan, do, check, analyze. Sedangkan konsep mutu Juran yang terkenal adalah trilogi Juran yaitu perencanaan kualitas, pengendalian kualitas, dan perbaikan kualitas. Semua konsep tersebut jika dapat diterapkan dalam dunia pendidikan akan memiliki dampak positif bagi peningkatan mutu pendidikan. Para tokoh seperti Philip Crosby pun menawarkan beberapa strategi untuk meningkatkan mutu. Hal tersebut dapat diadopsi bagi lembaga pendidikan untuk meningkatkan kualitasnya. Crosby menawarkan konsep Zero Defect yang dijabarkan lagi dalam empat belas langkah untuk diaplikasikan dalam setiap organisasi ataupun lembaga pendidikan agar dapat mengatur dan meningkatkan
\end{abstract}


mutu lembaga pendidikan. Setiap manajer atau pimpinan lembaga pendidikan seharusnya selalu berinovasi dan mengembangkan lembaga pendidikannya agar peserta didik dapat bersaing di era globalisasi.

Kata Kunci: Model Pengembangan Mutu Pendidikan, Pendidikan, Philip B. Crosby

\section{Pendahuluan}

Globalisasi sebagai bagian yang tidak terpisahkan dari kehidupan modern semakin nyata pengaruhnya dalam mewujudkan pasar dan persaingan bebas terbuka. Dalam keadaan seperti ini, semua lembaga khususnya pendidikan dituntut untuk mampu menciptakan efisiensi, mengutamakan mutu, kepuasan konsumen dan dapat memanfaatkan peluang dengan cepat agar dapat bersaing dan bertahan.

Adanya persaingan merupakan unsur yang tidak bisa ditawar lagi. Suatu organisasi atau lembaga dapat meningkatkan dan mempertahankan kualitas dengan cara membangun suatu sistem peningkatan kualitas dan menentukan standar (TQM) Total Quality Management atau disebut dengan manajemen peningkatan mutu, dan salah satu lembaga standarisasi dalam dunia industri diantaranya adalah ISO (International Organization for Standardization).

Dalam bidang pendidikan manajemen peningkatan mutu dapat didefinisikan sebagai sekumpulan prinsip dan tehnikyang menekankan pada peningkatan mutu dengan 42 bertumpu pada lembaga pendidikan untuk secara terus-menerus dan berkesinambungan meningkatkan kapasitas dan kemampuan lembaganya untuk memenuhi tuntuan kebutuhan peserta didik dan masyarakat dan mampu bersaing ditengah-tengah kemajuan globalisasi serta mampu bertahan dengan memproduk peserta didik berkualitas dan terpenuhinya kepuasan user atau stakeholder. ${ }^{1}$

Pada dasarnya anjuran untuk meningkatkan mutu telah dijelaskan di dalam Al Qur'an, bahwasanya seorang hamba harus berusaha memperbaiki diri dengan cara meningkatkan kualitas imannya, ibadahnya, serta ikhtiarnya agar menjadi pribadi yang memiliki kualitas yang lebih baik dari sebelumnya.

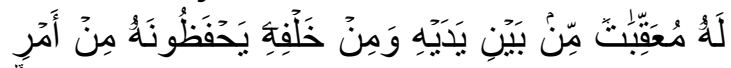

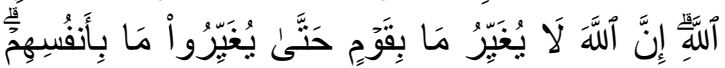

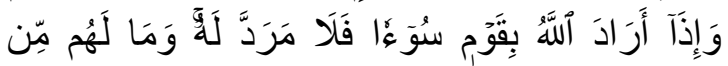

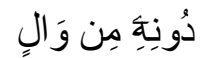

Terjemahnya: Bagi manusia ada malaikat-malaikat yang selalu mengikutinya bergiliran, di muka dan di belakangnya, mereka menjaganya

${ }^{1}$ Edward Sallis, Total Quality Management in Education. (London: Kogan Page, 2006), 40

el Bidayah: Journal of Islamic Elementary Education Volume 2, Number 1, March 2020 
atas perintah Allah. Sesungguhnya Allah tidak merubah keadaan sesuatu kaum sehingga mereka merubah keadaan yang ada pada diri mereka sendiri. Dan apabila Allah menghendaki keburukan terhadap sesuatu kaum, Maka tak ada yang dapat menolaknya; dan sekali-kali tak ada pelindung bagi mereka selain Dia. ${ }^{2}$

Melihat betapa pentingnya manajemen peningkatan mutu, untuk suatu lembaga pendidikan, khususnya lembaga pendidikan Islam di zaman globalisasi seperti ini agar tetap terlihat eksistensinya dan bahkan semakin tinggi dimasa-masa yang akan datang, maka selanjutnya akan dijelaskan bagaimana konsep pengembangan mutu menurut Philip Crosby untuk mengetahui bagaimana, strategi pembaharuan dari manajemen peningkatan mutu ini, agar kita benar-benar dalam mengimplementasikannya tujuan ideal sebuah lembaga pendidikan tercapai dan memuaskan pelanggan. Dengan demikian fokus pembahasan ini adalah model pengembangan mutu pendidikan dalam perspektif Philip Crosby.

\section{Metode}

Jenis penelitian yang digunakan dalam penelitian ini adalah kepustakaan (Library Reseach). Penelitian ini ditujukan untuk mengumpulkan data dan informasi dengan bantuan bermacam-macam

${ }^{2}$ Al-Qur'an, Surat Ar-Ra'd: 11 el Bidayah: Journal of Islamic Elementary Education Volume 2, Number 1, March 2020 material yang terdapat di ruangan perpustakaan seperti, buku-buku, majalah, dokumen catatan dan kisah kisah sejarah lainnya. Pada esensinya data yang telah diperoleh dengan penelitian perpustakaan ini dapat dijadikan landasan dasar dan instrumen utama bagi pelaksanaan penelitian lapangan. Penelitian ini juga di katakan membahas data-data sekunder. ${ }^{3}$

Dari definisi ini, maka dapat dipahami bahwa jenis penelitian kepustakaan (Library Reseach) adalah jenis penelitian yang menggunakan berbagai macam ragam yang terdapat di ruangan perpustakaan upaya untuk mengumpulkan data serta mendapatkan informasi yang valid. Dalam mengkaji bahan pustaka ada beberapa hal yang menjadi ramburambu peneliti dalam melakukan aktivitas penelitiannya. Oleh sebab itu ada beberapa pengklasifikasian tentang sumber bahan pustaka. Untuk memperoleh informasi mengenai teori dan hasil penelitian peneliti dapat mengkaji berbagai sumber yang dapat di klasifikasikan atas beberapa jenis bentuk diantaranya, klasifikasi menurut bentuk dan isi.

${ }^{3}$ Mardalis, metode Penelitian Suatu Pendekatan Proposal, Uakarta: Bumi Aksara, 2002), $h, 28$. 
Temuan

penelitian

pembahasan

\section{Temuan Penelitian}

1. Biografi Singkat Philip B. Crosby

Philip B. Crosby lahir di Wheeling, Virginia Barat pada 18 Juni 1926. Kehidupan kerja Mr. Crosby dimulai setelah masa tugas selama Perang Dunia II dan Konflik Korea dengan pendidikan di sekolah kedokteran. Dia bekerja untuk Crosley dari 1952-1955; untuk Bendix Mishawaka dari 1955 - 1957; dan Martin-Marietta 1957-1965. Pada tahun 1964, ia menerima Medal layanan sipil dari Departemen Angkatan Darat pada tahun 1964 untuk pengakuan tentang pengembangan konsep Zero Defects. Ia menjabat di bawah CEO ITT Harold Geneen sebagai Wakil Presiden Corporate Mutu dari 19651979, ketika ia mendirikan perusahaan konsultan sendiri.

Pada tahun 1979, ia mendirikan Philip Crosby Associates, Inc. (PCA), selama sepuluh tahun, tumbuh menjadi sebuah organisasi publik dengan 300 karyawan di seluruh dunia dan dengan pendapatan \$ 100 juta dolar. Melalui PCA Quality College, manajemen mempelajari bagaimana membangun budaya preventif untuk mendapatkan sesuatu dilakukan dengan benar pertama kalinya. GM, Chrysler, Motorola, Xerox, banyak rumah sakit, dan beberapa perusahaan di seluruh dunia datang pada PCA untuk memahami manajemen mutu. Filosofinya telah mendarah daging ke dalam serat dari perusahaan-perusahaan ini baik besar dan kecil.

Pada tahun 1991 ia pensiun dari PCA dan mendirikan Karir IV, Inc, sebuah perusahaan yang memberikan kuliah dan seminar yang bertujuan membantu eksekutif saat ini dan calon eksekutif. Pada tahun 1997 ia membeli aset PCA dan mendirikan Philip Crosby Associates II, Inc (PCA II). "Quality College" terus beroperasi di lebih dari 20 negara di seluruh dunia. Crosby menulis 13 buku tentang kualitas yang telah diterjemahkan ke dalam 17 bahasa dan telah terjual jutaan copy keduanya hard cover dan soft cover. Beberapa bukunya yang paling penting termasuk:

a. Cutting the Cost of Quality, 1967

b. Quality Is Free: The Art of Making Quality Certain, 1979

c. Quality Without Tears: The Art of Hassle-Free Management, 1984

d. Running Things: The Art of Making Things Happen, 1986

e. The Eternally Successful Organization, 1988

f. Let's Talk Quality, 1989

g. Leading: The Art of Becoming an Executive, 1990

h. Completeness: Quality for the 21st Century, 1992

i. Reflections on Quality, 1995

j. Quality Is Still Free, 1996 
k. The Absolutes of Leadership, 1997

1. Quality and Me: Lessons of an Evolving Life, 1999

Philip B. Crosby mendapatkan gelar sarjana dari Ohio College of Podiatric Medicine, gelar kehormatan sarjana hukum dari Wheeling College dan Rollins College, dan gelar kehormatan Doctor of Corpo-rate Management dari University of Findlay. Philip B. Crosby adalah seorang filsuf yang memiliki lebih dari 40 tahun pengalaman dalam manajemen. Dia mengajarkan manajemen bagaimana menyebabkan organisasi mereka, karyawan mereka, pemasok mereka, dan diri mereka sendiri untuk menjadi sukses. ${ }^{4}$

Crosby terkenal dengan anjuran manajemen zero defect dan pencegahan, yang menentang tingkat kualitas yang dapat diterima secara statistik (acceptable quality level). Dia juga dikenal dengan Quality Vaccine dan Crosby's Fourteen Steps to Quality Improvement.

\section{Konsep Mutu Philip B. Crosby}

Philip Crosby berpandangan bahwa mutu itu gratis, menurut ia terlalu banyak pemborosan dalam sistem saat mengupayakan peningkatan mutu. Philip Crosby juga berpendapat bahwa semua hal seperti kesalahan, kegagalan, pem-

\footnotetext{
Diakses dari http://www.philipcrosby.com/25years/crosby tanggal 04-02-2020, pukul 21.00 el Bidayah: Journal of Islamic Elementary Education Volume 2, Number 1, March 2020
}

borosan, dan penundaan waktu dapat dihilangkan jika institusi memiliki kemauan untuk itu. Kedua hal ini merupakan gagasan tanpa cacatnya yang kontroversial (zero defect). Jika pendapat Crosby ditarik dalam dunia pendidikan, sangat bermanfaat untuk peningkatan mutu pendidikan dengan menghilangkan kegagalan pelajar oleh sebagian institusi. Crosby bersama para guru secara ekstra berupaya bahwa tanpa cacat dapat diwujudkan walaupun sangat sulit. Philip B. Crosby menyatakan bahwa mutu adalah kesesuaian terhadap persyaratan atau keunggulan yang dipublikasikannya, seperti jam tahan air, sepatu yang awet, atau dokter yang ahli. Pendekatannya adalah top-down. ${ }^{5}$

Mutu (Kualitas) pendidikan bukan sesuatu yang terjadi dengan sendirinya, dia merupakan hasil dari suatu proses pendidikan, jika suatu proses pendidikan berjalan baik, efektif dan efisien, maka terbuka peluang yang sangat besar memperoleh hasil pendidikan yang bermutu. Mutu pendidikan mempunyai kontinum dari rendah ke tinggi sehingga berkedudukan sebagai suatu variabel, dalam konteks pendidikan sebagai suatu sistem, variabel kualitas pendidikan

5Etwar, Emin. 2011. Tokoh-tokoh Mutu Layanan.

(Online),(http//eminetwar.blogspot.com/ 2011/04/tokoh-tokoh mutu-layanan. html, diakses tanggal 06-02-2020 pukul 20.00 WIB 
dapat dipandang sebagai variabel terikat yang dipengaruhi oleh banyak faktor seperti kepemimpinan, iklim organisasi, kualifikasi guru, anggaran, kecukupan fasilitas belajar dan sebagainya. Edward Sallis menyatakan: "ada banyak sumber mutu dalam pendidikan, misalnya sarana gedung yang bagus, guru yang terkemuka, nilai moral yang tinggi, hasil ujian yang memuaskan, spesialisasi atau kejuruan, dorongan orang tua, bisnis dan komunitas lokal, sumberdaya yang melimpah, aplikasi teknologi mutakhir, kepemimpinan yang baik dan efektif, perhatian terhadap pelajar an anak didik, kurikulum yeng memadai, atau juga kombinasi dari faktor-faktor tersebut". ${ }^{6}$

Menurut Crosby, kemutlakan bagi kualitas adalah: (1) kualitas harus disesuaian sebagai kesesuaian terhadap kebutuhan-kebutuhan, bukan sebagai kebaikan, juga bukan keistimewaan, (2) sistem untuk menghasilkan kualitas adalah pencegahan bukan penilaian, (3) standar kerja harus tanpa cacat, bukan "cukup mendekati tanpa cacat", (4) pengukuran kualitas merupakan harga ketidaksesuaian, bukan pedoman. Karena itu, menurut tokoh yang sangat terkemuka dengan gagasan kualitas ini, bahwa manajemen adalah penyebab

6 Edward Sallis, Total Quality Management in Education. (London: Kogan Page, 2006), 30 setidak-tidaknya $80 \quad \%$ masalahmasalah kualitas di dalam organisasi. Karena itu, satu-satunya jalan memperbaikinya adalah melalui kepemimpinan manajemen. ${ }^{7}$

Crosby memberikan "vaksin kualitas" (Quality Vaccine), yaitu: (1) Tujuan: manajemen merupakan satu-satunya alat yang akan mengubah citra organisasi,

Pendidikan: membantu semua komponen organisasi mengembangkan satu pengertian umum tentang kualitas dan memahami peran mereka masing-masing di dalam proses perbaikan kualitas, (3) penerapan: membimbing dan mengarahkan program perbaikan. ${ }^{8}$

Menurut Crosby, setiap perusahaan harus divaksinasi agar memiliki antibodi untuk melawan ketidaksesuaian terhadap persyaratan (non-confronmances). Ketidaksesuaian ini merupakan sebab, sehingga harus dicegah dan dihilangkan. Dalam menyiapkan vaksinasi, suatu perusahaan perlu membuat lima unsur, yaitu: ${ }^{9}$

a. Integritas

CEO (Cheif Executive Officer) harus dapat menjamin bahwa pelanggan menerima apa yang telah dijanjikan, seperti kualitas produk/jasa, kua-

${ }^{7}$ P.B, Crosby, Quality is Free, The Art of making Quality Certain, (New York:-McGraw-Hill Book Co, 1986), 86

8 Philip Crosby, Quality without Tears The Art of Hassle Free Management, (New York:Mc.Graw Hill Inc, 1984), 6

${ }^{9}$ Crosby, Quality is Free..., 127

el Bidayah: Journal of Islamic Elementary Education Volume 2, Number 1, March 2020 
litas penyampaian, keamanan dan lain-lain. COO (Chief Operating Officer) harus memiliki pemikiran bahwa kualitas di atas segalagalanya.

b. Sistem

Sistem adalah serangkaian prosedur dan kegiatan individu di dalam tim untuk menjamin kualitas. Untuk itu diperlukan pendidikan kualitas yang merupakan proses untuk membantu karyawan agar memiliki bahasa yang sama dalam kualitas dan mengerti peran mereka dalam upaya peningkatan kualitas.

c. Komunikasi

Setelah memiliki bahasa yang sama, maka komunikasi akan lebih mudah terjalin. Komunikasi disini adalah proses mengirim dan menerima informasi mengenai kualitas dan mendukung peningkatan kualitas. Semua informasi mengenai usaha peningkatan kualitas disampaikan kepada seluruh karyawan.

d. Operasi

Operasi dalam kegiatan sehari-hari yang dilakukan organisasi untuk menjaga agar tetap berfungsi. Hal ini dilaksanakan dengan mendidik pemasok agar mengirim poduk dan jasa sesuai dengan persyaratan. Selain itu prosedur, produk dan sistem dikualifikasi dan dibuktikan sebelum pelaksanaan dan diuji secara terus-menerus.

e. Kebijakan

Dibutuhkan pula adanya pernyataan dan pengarahan dari manajemen yang memperjelas dimana mereka berdiri dan menentukan sikap tentang kualitas. Kebijakan harus jelas dan tidak ragu-ragu.

Dalam dunia pendidikan, seorang manajer atau kepala sekolah juga harus memberikan vaksin kualitas kepada bawahannya. Stakeholder berperan dalam tercapainya tujuan bersama. Seluruh komponen yang ada di sekolah harus menjamin integritasnya bahwa pelanggan benar-benar menerima kualitas yang diinginkan. Seluruh pihak harus berkomitmen bahwa kualitas adalah segala-galanya.

Setelah semua pihak di sekolah memiliki visi misi yang sama menguatkan integritasnya tentang kualitas, maka sistem harus benarbenar dijalankan sesuai dengan prosedur yang ditetapkan. Agar semua karyawan memiliki konsep yang sama tentang kualitas. Dalam hal ini diperlukan supervisor yang bertugas mengawasi berjalannya sistem, apakah sudah sesuai dengan prosedur yang berlaku atau sebaliknya.

Tidak hanya integritas dan sistem yang baik harus ditekankan pada semua pihak di sekolah, melainkan juga harus ada komunikasi yang baik dan berjalan seimbang antara pimpinan dan bawahan, kepala sekolah dan anggotanya. Pengkomunikasian tentang berjalannya kualitas atau evaluasi akan dilakukan dari 
bagaimana kekurangan anggota dalam pelaksanaan tercapainya kualitas sampai kepada prestasi anggota terhadap pelaksanaan kualitas.

Setelah komunikasi juga berjalan seimbang, maka operasi juga terus dilakukan berulang-ulang. Diadakannya training adalah salah satu cara untuk meningkatkan kompetensi anggota sekolah dalam meningkatkan kualitas lembaga. Selain itu juga terus dilakukan evaluasi pengujian yang bertahap guna memantau peningkatan dalam pelaksanaan sistem.

Seorang pimpinan dalam lembaga pendidikan disamping melihat semua aspek diatas juga perlu dan harus menentukan kebijakan kualitas yang jelas dan tidak ragu-ragu kepada bawahannya, disertai dengan alasan, standar, dan cara yang jelas dan terukur sehingga bawahan dapat memahami dan melaksanakan dengan sungguhsungguh sesuai dengan instruksi atasan. Semua hal tersebut pastilah bukan hal yang mudah. Karena dalam dunia pendidikan dimana lembaga menjual produk jasa untuk ditawarkan kepada pelanggan atau masyarakat. Akan tetapi jika pencegahan dilaksanakan lebih awal, maka akan mengurangi resikoresiko yang terjadi di masa mendatang.

Mengaplikasikan konsep tanpa cacat pada industri layanan jauh 48 lebih sulit dibandingkan pada industri produk. Dalam industri layanan, tanpa cacat adalah konsep yang sangat ideal, kenyataannya, sulit sekali menjamin sebuah layanan tanpa cacat di saat peluang terjadinya human error sangat besar. Meskipun demikian, tanpa cacat adalah sebuah industri layanan yang sangat penting. Ide ini adalah ide yang harus memiliki gaung dalam pendidikan. Metode tanpa cacat menginginkan agar seluruh peserta didik dapat memperoleh kesuksesan dan mengembangkan potensi mereka. Tugas peningkatan mutu dalam pendidikan adalah membangun sistem dan struktur yang menjamin terwujudnya metode tersebut. Memang, ada banyak pihak yang menentang metode tanpa cacat, terutama sekali ujian normatif yang memustahilkan tujuan metode tersebut, di samping itu, muncul pandangan bahwa standar-standar metode tanpa cacat hanya bisa diperoleh setelah melalui tingkat kegagalan yang tinggi. ${ }^{10}$

Dalam dunia pendidikan pasti banyak menjumpai permasalahan yang berhubungan dengan kualitas lembaga. Metode zero defect bertujuan untuk memberikan perencanaan yang maksimal dan pencegahan dini atau antisipasi yang terjadi di masa mendatang terhadap

10 Edward Salis, Total Quality Management in Education, (Yogyakarta:Diva Press, 2015), 98

el Bidayah: Journal of Islamic Elementary Education Volume 2, Number 1, March 2020 
permasalahan dan kemungkinan yang akan terjadi. Mengidentifikasi dan menetapkan beberapa program unggulan madrasah yang dirancang secara maksimal dengan mempertimbangkan sisi negatif dan positif akan mengurangi kegagalan program yang telah direncanakan oleh madrasah.

\section{Pengembangan}

Mutu

\section{Pendidikan Philip B. Crosby}

Philip B. Crosby dalam bukunya Quality is Free mengungkapkan empat dalil mutu seperti berikut ini: ${ }^{11}$

a. Definisi mutu adalah kesesuaian dengan persyaratan.

b. Sistem mutu adalah pencegahan.

c. Standar kerja adalah tanpa cacat.

d. Pengukuran mutu adalah biaya mutu.

Pendekatan lain dari mutu adalah "Zero Defect" atau tanpa cacat yang dikemukakan oleh Philip B. Crosby atau membuatnya benar sejak pertama kali (make it right the first time) yang dijabarkan ke dalam 14 elemen proses perbaikan mutu. ${ }^{12}$ Empat belas elemen tersebut dapat dikembangkan untuk meningkatkan mutu pendidikan sebagai berikut:

1. Komitmen manajemen (Management Commitment). Pastikan bahwa manajemen senior mengetahui bagaimana pencega-

\footnotetext{
11 P.B. Crosby, Quality is Free..., 95

12 Teguh Sriwidadi, Manajemen Mutu Terpadu, (UBINUS Jakarta: Jurnal The Winners, Vol. 2 No. 2, September 2001), 107-115 el Bidayah: Journal of Islamic Elementary Education Volume 2, Number 1, March 2020
}

han kesalahan dapat memperbaiki mutu dan mengurangi biaya. Susun kebijakan mutu yang menyatakan bahwa setiap individu harus sungguh-sungguh memenuhi persyaratan kerja yang diperlukan atau diubah menjadi apa yang kita dan pelanggan perlukan. Menyetujui bahwa perbaikan mutu merupakan cara yang praktis untuk meningkatkan keuntungan.

2. Tim perbaikan mutu (Quality Improvement Team). Tim ini terdiri dari 1 anggota dari setiap departemen dalam perusahaan. Seseorang dapat ditunjuk yang sepakat agar departemen mengambil tindakan, terutama departemen pusat. Kegunaan tim ini untuk mengimplementasikan program mutu ke seluruh bagian perusahaan.

3. Pengukuran mutu (Quality Measurement). Mengembangkan pengukuran mutu dalam semua bagian perusahaan. Pengukuran ini digunakan untuk menentukan tindakan perbaikan dan mengukur kemajuannya di waktuwaktu yang akan datang. Pengukuran tidak hanya dikembangkan untuk produk saja tetapi juga pada operasi di bidang jasa, kantor, dan juga untuk para penjual.

4. Evaluasi biaya mutu (Cost of Quality Evaluation). Biaya mutu harus didefinisikan. Akuntan 
harus memikul tanggungjawab atas pengukuran mutu karena hal ini menghilangkan suatu suspected bias. Manajemen akan perlu untuk terlibat tetapi praktik akuntansi yang lalu berubah untuk mencerminkan biaya mutu yang sebenarnya.

5. Kesadaran mutu (Quality Awareness). Dalam langkah ini, karyawan dibuat agar sadar akan program perbaikan mutu melalui penyelia mereka. Program ini bukan merupakan program motivasi tetapi lebih ditekankan pada usaha untuk menunjukkan kepada pekerja dengan akibat mutu yang rendah terhadap pelanggan, biaya, persaingan dan pekerjaan mereka.

6. Tindakan perbaikan (Corrective Action). Tindakan perbaikan ini harus diusulkan oleh para karyawan dan penyelia. Pertemuan mingguan diadakan pada setiap level untuk membahas masalah mutu.

7. Komite $A d$ Hoc untuk program Zero Defect. Tiga atau empat anggota tim perbaikan mutu, ditugaskan pada $A d \quad H o c$ Committee untuk menginvestigasi konsep Zero Defect dan mencari cara untuk mengkomunikasikan program kepada karyawan (melalui pertemuan, poster, dan sebagainya). Program ini bukan relasi publik melainkan usaha untuk menerangkan bagaimana segala sesuatu harus dikerjakan dengan benar sejak pertama kali.

8. Pelatihan penyelia (Supervisor Training). Program yang formal diadakan untuk mendidik para manajer pada setiap level mengenai konsep Zero Defect.

9. Hari Zero Defect. Satu hari khusus ditentukan untuk menjelaskan kepada seluruh karyawan mengenai Zero Defect sehingga mereka mengetahui konsepnya dengan cara yang sama. Standar Zero Defect harus secara tegas ditentukan pada hari tersebut.

10.Penentuan sasaran (Goal Setting). Penyelia minta kepada setiap pekerja untuk menentukan sasaran mutu untuk 30,60, dan 90 hari. Sasaran itu harus dapat diukur dan spesifik.

11.Penghapusan penyebab kesalahan (Error Cause Removal). Setiap pekerja diminta untuk menjelaskan masalah yang dihadapi. Kemudian, kelompok fungsional tertentu ditugaskan untuk memeriksa setiap masalah yang terjadi dan mengusulkan cara pemecahannya.

12.Penghargaan/pengakuan

(Recognition). Penghargaan diperlukan untuk melengkapi tindakan yang positif dalam menghilangkan suatu penyebab kesalahan. Berbagai macam penghargaan dapat diberikan, misalnya dalam bentuk cincin 
emas, makan malam, atau bendabenda lainnya.

13. Dewan mutu (Quality Council). Profesional mutu dan pemimpinpemimpin tim dari berbagai bagian membentuk dewan mutu. Mereka mengadakan pertemuan secara periodik untuk saling menyampaikan ide dan berkomunikasi mengenai program masing-masing.

14. Lakukan berulang kali (Do it Over Again). Program yang khusus memerlukan waktu 1 tahun sampai 18 bulan. Selama kurun waktu tersebut, pengetahuan tentang program dapat mengalami perubahan. Program harus dimulai lagi dengan tim yang baru. Hari Zero Defect harus diadakan setahun sekali seperti hari ulang tahun. Program ZD harus terus menerus diadakan sehingga merupakan budaya perusahaan. Jika mutu bukan merupakan pandangan hidup (way of life) maka tidak akan ada perbaikan. ${ }^{13}$

Empat belas hal yang dikemukakan oleh Crosby tentunya akan sangat sulit dilakukan oleh lembaga pendidikan jika tidak ada komitmen yang kuat oleh seluruh pihak stakeholder yang ada dalam lembaga tersebut. Merencanakan dan menjaga hal yang sedemikian rupa tentunya disamping harus diawali dari manajer yang visioner, juga harus terus membina dan mengevaluasi secara bertahap guna tercapainya program di lembaga. Beberapa hal yang perlu dilakukan untuk memotivasi para anggota di lembaga pendidikan, mulai dari slogan yang diadakan di lembaga sampai kepada pelatihan mengajar ataupun peningkatan kompetensi akan membantu anggota untuk mewujudkan program lembaga. Program yang sudah direncanakan bersama seharusnya terus menerus diadakan sehingga membudaya dalam lembaga, jika sudah membudaya maka kesadaran untuk selalu meningkatkan mutu pendidikan akan selalu terjaga.

\section{Hasil dan Pembahasan}

Ada beberapa konsep mutu menurut para ahli seperti Edward Deming dan Juran. Ada 14 poin W Edward Deming yang termasyhur dan merupakan kombinasi baru tentang manajemen mutu dan seruan terhadap manajemen untuk merubah pendekatannya, diantaranya; [a] Ciptakan sebuah usaha peningkatan produk dan jasa dengan tujuan agar bisa kompetitif dan tetap berjalan serta menyediakan lowongan pekerjaan, [b] Adopsi falsafah baru, [c] Hindari ketergantungan inspeksi massa untuk mencapai mutu, [d] Akhiri praktek menghargai bisnis dengan harga, [e] Tingkatkan dengan secara 
konstan sistem produksi dan jasa untuk meningkatkan mutu dan produktivitas, [f] Lembagakan pelatihan kerja, [g] Lembagakan kepemimpinan, [h] Hilangkan rasa takut agar setiap orang dapat bekerja secara efektif, [i] Uraikan kendala-kendala antar departemen, [j] Hapuskan slogan, desakan dan target serta tingkatkan produktifitas tanpa menambah beban kerja, k) Hapuskan standar kerja yang menggunakan quota numerik, [1] Hilangkan kendala-kendala yang merampas kebanggaan karyawan atas keahliannya, m) Lembagakan aneka program pendidikan yang meningkatkan semangat dan peningkatan kwalitas kerja, [n] Tempatkan setiap orang dalam tim kerja agar dapat melakukan transformasi. ${ }^{14}$

Dari 14 poin yang diutarakan Edward Deming diatas dianalisis atau dilihat dari kepuasan pihak konsumen, dalam hal ini yang dimaksud adalah para peserta didik dan masyarakat yang bersangkutan dalam dunia pendidikan.

Dalam merencanakan mutu pendidikan Josep Juran menggunakan pendekatan SQM (Strategy Quality Management), tiga proses mutu tersebut diantaranya adalah a) Perencanaan mutu (quality planning) yang meliputi kualitas pelanggan, menentukan kebutuhan pelanggan, menyusun sasaran mutu, dan meningkatkan kemampuan proses, b) Pengendalian mutu (quality control), terdiri dari memilih dasar pengendalian, memilih jenis pengukuran, menyusun standar kerja, dan mengukur kinerja yang sesungguhnya, c) perbaikan dan peningkatan mutu (quality improvement) yang meliputi mengidentifikasi perbaikan khusus, mengorganisasi lembaga untuk mendiagonis kesalahan, menemukan penyebab kesalahan peningkatan kebutuhan untuk mengadakan perbaikan. ${ }^{15}$

Menurut Philip B Crosby, Mutu ialah conformance to requirement, yaitu sesuai dengan yang disyaratkan atau distandarkan. Suatu produk memiliki mutu apabila sesuai dengan standar atau kriteria mutu yang telah ditentukan, standar mutu tersebut meliputi bahan baku, proses produksi, dan produk jadi.

Philip Crosby menyatakan bahwa sebuah langkah sistematis untuk mewujudkan mutu akan menghasilkan mutu yang baik. Penghematan sebuah institusi akan datang dengan sendirinya ketika institusi tersebut melakukan segala sesuatunya dengan benar. Selalu berusaha agar berhati-hati dalam setiap langkah yang meliputi input, seperti bahan ajar (kognitif, afektif dan psikomotorik) metodologi,

${ }^{14}$ Edwards, Deming $\mathrm{W}$, Out of The Crisis, (Cambridge University Press, 1986), 158 (New York, McMillan Company, 1989), 107 
sarana prasarana dan sumber daya lainnya. Sedangkan Mutu dalam kontek hasil pendidikan mengacu pada perestasi yang dicapai oleh sekolah pada setiap kurun tertentu.

Mutu atau kualitas yang ada dalam setiap lembaga pendidikan yang satu dengan yang lain pasti berbeda. Kualitas yang ada berdasarkan keunggulan yang ada dalam lembaga pendidikan. Mutu tersebut dapat dilihat dari prestasi siswa dan lembaga di tingkat daerah atau nasional, hasil ujian akhir nasional, atau berdasarkan input dan output serta outcomes-nya. Beberapa lembaga yang telah menerapkan program-program peningkatan mutu lembaga pendidikan diantaranya adalah sebagai berikut: 16

a. MI Muhammadiyah 1 Pare Kediri

Lembaga pendidikan ini memiliki ciri khas kelas LCP dan reguler. Kelas LCP (Language Class Programe) yang berisi kelas yang kurikulumnya meliputi pembelajaran beberapa mata pelajaran dengan menggunakan bahasa Inggris, sedangkan kelas reguler adalah kurikulum nasional dengan menggunakan bahasa Indonesia sebagai pengantar bahasanya. Sesuai dengan konsep Crosby maka metode zero defect yang diterapkan di lembaga ini adalah menjaring perekrutan siswa untuk program

16 Hasil observasi dan wawancara penulis periode Desember 2012 dan Mei 2017
LCP yang sesuai dengan bakat dan kemampuannya berdasarkan tes IQ dan tes bahasa. Hal ini bertujuan untuk memudahkan para guru dalam membina dan mengembangkan bakat dan kemampuan peserta didik.

b. MI Ar-Rahmah Purwotengah Papar Kediri

Lembaga pendidikan ini terletak di pedesaan namun tidak kalah dengan lembaga pendidikan yang ada di perkotaan. MI ini menerapkan pembiasaan pembiasaan kepada para siswa setiap pagi sebelum pelajaran dimulai. Pembiasaan yang dilakukan diantaranya berhitung, menghafal surat-surat pendek, kosakata bahasa Inggris dan Arab. Program itu dilakukan rutin setiap hari, agar siswa semakin terasah kemampuan berhitung, bahasa, dan lainnya. Hal ini seperti salah satu dari 14 pendapat Crosby bahwa sesuatu harus dilakukan berulang kali agar dapat terbiasa melakukan dan akan meningkatkan mutu madrasah.

c. MI Kunuzunnajah Purwoasri Kediri

MI ini terletak di kecamatan Purwoasri Kediri. Pada mulanya MI ini memiliki keterbatasan siswa yang sedikit, kemudian madrasah yang berada di bawah yayasan keluarga ini bangkit dan memiliki terobosan agar orangtua tertarik menyekolahkan anaknya di madrasah tersebut. Pihak madrasah 
menyediakan jasa transportasi sekolah untuk mengantar dan menjemput siswanya, disamping itu gratis tanpa dipungut biaya, beserta biaya pendidikan pun gratis, pada saat ini siswa sudah semakin banyak dan ke depannya akan meningkatkan mutu lembaganya. Komunikasi yang terjalin antara pihak madrasah dan yayasan juga berjalan seimbang, berkaitan dengan berjalannya semua program yang ada di madrasah, seperti halnya Crosby mengemukakan bahwa harus ada dewan mutu dalam terbentuknya suatu lembaga, agar ada komunikasi yang seimbang antara atasan dan bawahan dalam meningkatkan kualitas lembaga.

d. MIN 1 Malang

MIN 1 Malang terdapat banyak slogan-slogan dan poster yang berisikan tentang kebersihan, ilmu, motivasi, perintah dan larangan untuk semua anggota sekolah. Slogan-slogan yang dibuat menjadi anjuran dan peringatan serta motivasi untuk semua anggota sekolah. Slogan dan poster dipasang di sudut-sudut taman sekolah bahkan juga di dalam kelas. Hal tersebut bertujuan untuk setiap warga sekolah agar selalu ingat dengan tujuan bersama. Seperti vaksin kualitas yang dikemukakan oleh Crosby yang bertujuan untuk memberi imunisasi motivasi kepada warga sekolah untuk meningkatkan mutu lembaganya.

e. SDIT Baitul Izzah Nganjuk 54
SDIT Baitul Izzah Nganjuk ini adalah sekolah yang memiliki ciri khas kurikulum nasional dan kurikulum Cambridge. Tiga mata pelajaran yang mengikuti kurikulum Cambridge adalah matematika, sains, dan bahasa Inggris. Vaksin kualitas yang diberikan kepada siswa adalah dengan memberikan pembiasaan hafalan vocabulary bahasa Inggris setiap pagi juga hafalan surat-surat pendek, sedangkan untuk guru adalah dengan diadakannya training untuk peningkatan kompetensi guru. Pada tahap rekrutmen sekolah pun memiliki seleksi ketat untuk rekrutmen guru baik dari segi kualifikasi jenjang pendidikan juga kemampuan yang lain.

f. IIS PSM Magetan

Islamic International School Pesantren Sabilul Muttaqin Magetan ini adalah sekolah yang didirikan oleh Bapak Dahlan Iskan. Sekolah ini juga berafiliasi dengan madrasah AlIrsyad Islamiyah Singapura. Seringkali sekolah ini mengadakan studi banding ke Singapura guna untuk meningkatkan kualitas profesional guru sehingga dapat mengaplikasikannya di sekolah. Sekolah ini memiliki jenjang TK sampai SMP. Pengantar bahasa yang digunakan adalah bahasa Inggris.

\section{Kesimpulan}

Kualitas pendidikan sangat diperlukan dalam peningkatan Volume 2, Number 1, March 2020 
sumber daya manusia yang bermutu dan siap bersaing dalam era globalisasi, hal tersebut menuntut para manajer atau pimpinan lembaga pendidikan untuk selalu berinovasi dalam me-manage lembaganya masing-masing agar terus terjaga eksistensinya dalam dunia pendidikan. Manajemen peningkatan mutu yang ditawarkan Philip Crosby diantaranya dapat dijadikan panduan untuk mengembangkan mutu pendidikan. Philip Crosby terkenal dengan Zero Defect-nya yang artinya tanpa cacat. Hal ini memberikan tawaran bagi pengemban lembaga pendidikan untuk berusaha memberikan yang terbaik dengan mengurangi segala kesalahan atau kegagalan yang terjadi di dalam melaksanakan tugas masing-masing. Konsep tersebut kemudian dikembangkan lagi menjadi 14 poin yang dapat dijadikan acuan dalam peningkatan mutu lembaga pendidikan. Baik Philip Crosby maupun tokoh-tokoh mutu sebelumnya menjelaskan bahwa peran seorang pemimpin sangat menentukan kemajuan dari kualitas lembaga pendidikan. Maka untuk melaksanakan konsep oleh para tokoh tersebut diperlukan pemimpin yang mempunyai semangat transformatif kualitas pendidikan yang lebih baik ke depannya.

\section{Daftar Pustaka}

Al-Qur'an Surat Ar-Ra'd ayat 11

Crosby, Philip B. Quality is Free, The Art of making Quality Certain, New York:-McGraw-Hill Book Co, 1986

Crosby, Philip. Quality without Tears The Art of Hassle Free Management. New York: Mc.Graw Hill Inc, 1984.

Deming $\mathrm{W}$, Edwards. Out of The Crisis, Cambridge University Press, 1986.

Etwar, Emin. "Tokoh-tokoh Mutu Layanan".

(Online),(http//eminetwar.blogs pot.com/2011/04/tokoh-tokohmutu-layanan.

2011.http://www.philipcrosby.c om/25years/crosby.html

Juran M, Joseph. Juran on Quality By Design, New York, McMillan Company, 1989.

Sallis, Edward.Total Quality Management in Education. London: Kogan Page, 2006

Sallis, Edward. Total Quality Managementin Education. Yogyakarta: Diva Press, 2015 Sriwidadi, Teguh.Manajemen Mutu Terpadu. UBINUS Jakarta: Jurnal The Winners, (2001), Vol. 2 No. 2 
Model Pengembangan Mutu Pendidikan....

Oleh: Marita Lailia Rahman 